\title{
Automated sequencing of complete mitochondrial genomes from laser- capture microdissected samples
}

\author{
Beau A. Aldridge, So Dug Lim, Amanda K. Baumann, Seyed Hosseini \\ Whitney Buck, Tara L. Almekinder, Carrie Q. Sun, and John A. Petros \\ Emory University, Atlanta, GA, USA
}

BioTechniques 35:606-612 (September 2003)

Mitochondrial DNA mutations have been related to both aging and a variety of diseases such as cancer. Due to the relatively small size of the genome $(16 \mathrm{~kb})$ and with the use of automated DNA sequencing, the entire genome can be sequenced from clinical specimens in days. We present a reliable approach to complete mitochondrial genome sequencing from laser-capture microdissected human clinical cancer specimens that overcomes the inherent limitations of relatively small tissue samples and partial DNA degradation, which are unavoidable when laser-capture microdissection is used to attain pure populations of cells from heterogeneous tissues obtained from surgical procedures. The acquisition of sufficient template combined with a standard set of 18 pairs of PCR primers allows for the efficient amplification of the genome. Subsequent single-stranded amplification is performed using 36 sequencing primers, and samples are run on an ABI PRISM ${ }^{\circledR} 3100$ Genetic Analyzer. The use of this procedure should allow even investigators with little experience sequencing from clinical specimens success in complete mitochondrial genome sequencing.

\section{INTRODUCTION}

The human mitochondrial genome is a 16-kb circular, double-stranded DNA molecule that encodes 13 mitochondrial proteins, 22 transfer RNAs, and 2 ribosomal RNAs. Mutations of this genome have been implicated in cancer, disease, and aging (1-3). To understand the mechanisms of mutation and the mitochondrial genotypes that lead to disease, pure populations of diseased and normal cells from clinical samples are required for a whole genome sequence comparison $(4,5)$.

One method that allows for the separation of morphologically distinct diseased and normal cells from heterogeneous tissue sections is lasercapture microdissection (LCM). This technique utilizes a transparent thermoplastic film mounted on a glass cap. The film is placed on top of a tissue section and activated by a laser. Upon activation, the film melts and bonds to the cells of interest. When the film is removed, selected cells remain embedded in the film. The samples can then be processed for DNA extraction, RNA analysis, or other assays $(6,7)$.

Although LCM is a valuable tool for the separation of populations of cells, small cell yields and poor DNA quality may present a major obstacle to further processing (8). Thus, the consistent PCR amplification of complete mitochondrial genomes from LCM samples has yet to be accomplished. In our study, we have successfully designed a system for the amplification and automated sequencing of entire human mitochondrial genomes from LCMacquired surgical specimens.

\section{MATERIALS AND METHODS}

\section{Overall Strategy}

Our system consists of 18 (approximately $1 \mathrm{~kb}$ each) double-stranded reactions (Table 1), followed by 36 single-stranded reactions (Table 2). The primary PCR products are large enough to allow for long sequencing runs but small enough to permit amplification from the relatively lowquality DNA template obtained from clinical LCM samples (9). In addition, all of the double-stranded reactions have the same annealing temperature $\left(55^{\circ} \mathrm{C}\right)$ and $\mathrm{MgCl}_{2}$ salt concentration (1.5 mM). These key features promote accurate and efficient primary PCR amplification. To further increase the efficiency of this process, we employed the ABI PRISM ${ }^{\circledR} 3100$ Genetic Analyzer (Applied Biosystems, Foster City, CA, USA) for the automated sequencing of the single-stranded PCR products. This machine can sequence an entire mitochondrial genome in less than 15 $\mathrm{h}$, which is a substantial improvement over manual Sanger sequencing. The entire process from microdissection to sequencing can take fewer than $72 \mathrm{~h}$. This system greatly simplifies and expedites the task of mitochondrial DNA sequencing from LCM samples and has proven to be a valuable tool for comparing mitochondrial DNA in diseased and normal tissues.

\section{Tissue Source}

The tissues for our study were acquired from patients at Emory University Hospital (Atlanta, GA, USA) who had signed informed consent and were undergoing radical prostatectomies. Within 30 min of surgery, the prostate tissue specimens were embedded in Cryomatrix ${ }^{\mathrm{TM}}$ Frozen Specimen Embedding Medium (Thermo Shandon, Pittsburgh, PA, USA) and then stored at $-80^{\circ} \mathrm{C}$.

\section{Tissue Sectioning}

Immediately before microdissection, the samples were sectioned at $8 \mu \mathrm{m}$ and $-22^{\circ} \mathrm{C}$ using a Cryotome ${ }^{\circledR}$ Electronic Cryostat (Thermo Shandon). The sample sections were placed on nonadhesive glass microscope slides (Fisher Scientific, Pittsburgh, PA, USA) and fixed with $70 \%$ ethanol for $1 \mathrm{~min}$. Tissues were then rinsed with deionized water for $15 \mathrm{~s}$ and stained with Mayer's hematoxylin for 15 s. After this staining, the samples were dehydrated with $70 \%$ ethanol, followed by $95 \%$ ethanol for 1 min each. Eosin was applied for $15 \mathrm{~s}$. The samples were then dehydrated in an increasing series of ethanol washes $(95 \%$ ethanol for 1 min, $100 \%$ ethanol for $1 \mathrm{~min}$, and then $100 \%$ ethanol for $1 \mathrm{~min}$ ) and cleared in xylene (twice for 2 min each). 
Table 1. Primary PCR Primers

\begin{tabular}{|c|c|c|c|c|}
\hline Region & Name & Sequence & Position $^{a}$ & $\begin{array}{l}\text { Size } \\
\text { (bp) }\end{array}$ \\
\hline 1 & $\begin{array}{l}1 \mathrm{~F} \\
1064 \mathrm{R}\end{array}$ & $\begin{array}{l}\text { 5'-GATCACAGGTCTATCACCCT-3' } \\
\text { 5'-GTCTTAGCTATTGTGTGTTC-3' }\end{array}$ & $\begin{array}{l}1-20 \\
1064-1045\end{array}$ & 1064 \\
\hline 2 & $\begin{array}{l}919 \mathrm{~F} \\
2079 \mathrm{R}\end{array}$ & 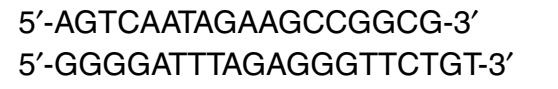 & $\begin{array}{l}\text { 919-936 } \\
2079-2060\end{array}$ & 1161 \\
\hline 3 & $\begin{array}{l}2001 F \\
2950 R\end{array}$ & $\begin{array}{l}\text { 5'-CGAGCCTGGTGATAGCTGGT-3' } \\
\text { 5'-AGGATTGCGCTGTTATCCCT-3' }\end{array}$ & $\begin{array}{l}2001-2020 \\
2950-2931\end{array}$ & 950 \\
\hline 4 & $\begin{array}{l}2851 \mathrm{~F} \\
3745 \mathrm{R}\end{array}$ & $\begin{array}{l}\text { 5'-ACATGCTAAGACTTCACCAG-3' } \\
\text { 5'-CTAGGGTGACTTCATATGAG-3' }\end{array}$ & $\begin{array}{l}2851-2870 \\
3745-3726\end{array}$ & 895 \\
\hline 5 & $\begin{array}{l}3641 \mathrm{~F} \\
4680 \mathrm{R}\end{array}$ & $\begin{array}{l}\text { 5'-CCGTTTACTCAATCCTCTGA-3' } \\
\text { 5'-GAAGGATTATGGATGCGGTT-3' }\end{array}$ & $\begin{array}{l}3641-3660 \\
4680-4661\end{array}$ & 1040 \\
\hline 6 & $\begin{array}{l}4561 F \\
5930 R\end{array}$ & $\begin{array}{l}\text { 5'-TAGGCCTAGAAATAAACATG-3' } \\
\text { 5'-AGAGAATAGTCAACGGTCGG-3' }\end{array}$ & $\begin{array}{l}4561-4580 \\
5930-5911\end{array}$ & 1370 \\
\hline 7 & $\begin{array}{l}5772 \mathrm{~F} \\
6720 \mathrm{R}\end{array}$ & $\begin{array}{l}\text { 5'-AGGTTTGAAGCTGCTTCTTC-3' } \\
\text { 5'-TACCTATGTATCCAAATGGT-3' }\end{array}$ & $\begin{array}{l}5771-5790 \\
6720-6701\end{array}$ & 950 \\
\hline 8 & $\begin{array}{l}6511 \mathrm{~F} \\
7600 \mathrm{R}\end{array}$ & $\begin{array}{l}\text { 5'-CTGCTGGCATCACTATACTA-3' } \\
\text { 5'-CGCTGCATGTGCCATTAAGA-3' }\end{array}$ & $\begin{array}{l}6511-6530 \\
7600-7581\end{array}$ & 1090 \\
\hline 9 & $\begin{array}{l}7411 \mathrm{~F} \\
8430 \mathrm{R}\end{array}$ & $\begin{array}{l}\text { 5'-ACACATTCGAAGAACCCGTA-3' } \\
\text { 5'-AGGAATAGTGTAAGGAGTAT-3' }\end{array}$ & $\begin{array}{l}7411-7430 \\
8430-8411\end{array}$ & 1020 \\
\hline 10 & $\begin{array}{l}8351 \mathrm{~F} \\
9361 \mathrm{R}\end{array}$ & $\begin{array}{l}\text { 5'-CCTCTTTACAGTGAAATGCC- } 3^{\prime} \\
\text { 5'-CCATCATTGGTATATGGTTA-3' }\end{array}$ & $\begin{array}{l}8351-8370 \\
9380-9361\end{array}$ & 1030 \\
\hline 11 & $\begin{array}{l}9301 \mathrm{~F} \\
10301 \mathrm{R}\end{array}$ & $\begin{array}{l}\text { 5'-CCATGTGATTTCACTTCCAC-3' } \\
\text { 5'-CTATTAGTGGCAGGTTAGTT-3' }\end{array}$ & $\begin{array}{l}9301-9320 \\
10,320-10,301\end{array}$ & 1020 \\
\hline 12 & $\begin{array}{l}10140 \mathrm{~F} \\
11180 \mathrm{R}\end{array}$ & $\begin{array}{l}\text { 5'-CCACAACTCAACGGCTACAT-3' } \\
\text { 5'-TTCAGGCGTTCTGGCTGGTT-3' }\end{array}$ & $\begin{array}{l}10,131-10,150 \\
11,190-11,171\end{array}$ & 1060 \\
\hline 13 & $\begin{array}{l}11010 \mathrm{~F} \\
11960 \mathrm{R}\end{array}$ & $\begin{array}{l}\text { 5'-AACGCCACTTATCCAGTGAA-3' } \\
\text { 5'-GTATGTTGAGTCCTGTAAGT-3' }\end{array}$ & $\begin{array}{l}11,001-11,020 \\
11,960-11,941\end{array}$ & 960 \\
\hline 14 & $\begin{array}{l}11900 \mathrm{~F} \\
12900 \mathrm{R}\end{array}$ & $\begin{array}{l}\text { 5'-GAACTCTCTGTGCTAGTAAC-3' } \\
\text { 5'-TCATGCTAAGGCGAGGATGA-3' }\end{array}$ & $\begin{array}{l}11,891-11,910 \\
12,900-12,881\end{array}$ & 1010 \\
\hline 15 & $\begin{array}{l}12750 \mathrm{~F} \\
13860 \mathrm{R}\end{array}$ & $\begin{array}{l}\text { 5'-CAACCTATTCCAACTGTTCA-3' } \\
\text { 5'-GGTTAGGTAGTTGAGGTCTA-3' }\end{array}$ & $\begin{array}{l}12,741-12,760 \\
13,860-13,841\end{array}$ & 1120 \\
\hline 16 & $\begin{array}{l}13710 \mathrm{~F} \\
14690 \mathrm{R}\end{array}$ & $\begin{array}{l}\text { 5'-ACGCCTGGCAGCCGGAAGCC-3' } \\
\text { 5'-GTCGTGGTGTAGTCCGTGC-3' }\end{array}$ & $\begin{array}{l}13,701-13,720 \\
14,700-14,681\end{array}$ & 1000 \\
\hline 17 & $\begin{array}{l}14590 \mathrm{~F} \\
15580 \mathrm{R}\end{array}$ & $\begin{array}{l}\text { 5'-TACTAAACCCCCATAAATAG-3' } \\
\text { 5'-GGAGAATTGTGTAGGCGAAT-3' }\end{array}$ & $\begin{array}{l}14,581-14,600 \\
15,590-15,571\end{array}$ & 1010 \\
\hline 18 & $\begin{array}{l}15510 \mathrm{~F} \\
90 \mathrm{R}\end{array}$ & $\begin{array}{l}\text { 5'-ACCCAGACAATTATACCCTA-3' } \\
\text { 5'-CAGCGTCTCGCAATGCTATC-3' }\end{array}$ & $\begin{array}{l}15,501-15,520 \\
100-81\end{array}$ & 1169 \\
\hline \multicolumn{5}{|c|}{$\begin{array}{l}\text { Sense primers are designated as forward }(\mathrm{F}) \text {, and antisense primers are desig- } \\
\text { nated as reverse }(\mathrm{R}) \text {. Double-stranded primer pairs were empirically determined by } \\
\text { randomly matching groups of five forward primers with five reverse primers. } \\
\text { aPosition refers to the } 5^{\prime} \text { and } 3^{\prime} \text { locations of each primer in reference to the } \\
\text { Cambridge mitochondrial genome sequence (http://www.mitomap.org). }\end{array}$} \\
\hline
\end{tabular}

\section{Laser-Capture Microdissection}

After allowing the samples to airdry for 5 min, a transparent CapSure ${ }^{\mathrm{TM}}$ Macro Cap (Arcturus Engineering, Mountain View, CA, USA) coated with a thermoplastic film was positioned on the tissue section's area of interest, and the entire slide was placed in the PixCell ${ }^{\circledR}$ IIe Laser Capture Microdissection Instrument (Arcturus Engineering). The samples were microscopically examined for morphological characteristics to distinguish between tumor and normal tissues. Carcinoma and benign epithelium of the prostate were captured separately using a 7.5$\mu \mathrm{m}$ diameter laser spot, $1.0-1.5 \mathrm{~ms}$ duration time, $55-65 \mathrm{~mW}$ power, and 4000-5000 targeted shots for each cap. The cells of interest were attached to the film when the low-power infrared laser was activated, which melted the special thermoplastic film over the cells. After collecting one cell type (tumor or normal), the cap, along with approximately 5000 bound cells, was removed from the section and placed in a $0.5-\mathrm{mL}$ microcentrifuge tube. The entire process of collecting one cap took about $30 \mathrm{~min}$, and the protocol was repeated when another cap was placed on a new section of tissue. Multiple caps (3-5) were collected for each tissue condition. Therefore, more than 20,000 cells were frequently collected from an individual prostate cancer and matched benign lesion. This number of cells was more than adequate for our experimental system and could be obtained through LCM in a reasonably short period of time. All samples were stored at $-80^{\circ} \mathrm{C}$ until processing.

\section{Proteinase Digestion}

For one condition (tumor or normal), three films were peeled off of the CapSure cap with a sterile razor blade and sharp forceps. The films were placed near the open end and along the wall of a microcentrifuge tube. The removal of the films from the LCM caps allowed for cells from the same condition to be digested together, pooling the DNA and increasing the concentration and consistency of the results (10). Fifty microliters of proteinase $\mathrm{K}$ buffer $[1 \mathrm{mg} / \mathrm{mL}$ pro- 
Table 2. Sequencing Primers

\begin{tabular}{|c|c|c|}
\hline Name & Sequence & Position \\
\hline $430 \mathrm{~F}$ & 5'-CGGTATGCACTTTTAACAGT-3' & $411-430$ \\
\hline $636 \mathrm{R}$ & 5'-TGATGTGAGCCCGTCTAAAC-3' & $636-617$ \\
\hline $1360 \mathrm{~F}$ & 5'-CCATGAGGTGGCAAGAAATG-3' & $1341-1360$ \\
\hline 1600R & 5'-TGTGTTAAGCTACACTCTGG-3' & $1620-1601$ \\
\hline $2352 \mathrm{~F}$ & 5'-GCATAAGCCTGCGTCAGATT-3' & 2333-2352 \\
\hline 2580R & 5'-TATGCTACCTTTGCACGGTT-3' & $2600-2581$ \\
\hline $3150 \mathrm{~F}$ & 5'-GGACAAGAGAAATAAGGCCT-3' & $3131-3150$ \\
\hline 3390R & 5'-TTGCGTAGTTGTATATAGCC-3' & 3410-3391 \\
\hline $4040 \mathrm{~F}$ & 5'-ACTACAATCTTCCTAGGAAC-3' & $4021-4040$ \\
\hline 4280R & 5'-TACTCTATCAAAGTAACTCT-3' & $4300-4281$ \\
\hline $5130 \mathrm{~F}$ & 5'-CGCATTCCTACTACTCAACT-3' & $5111-5130$ \\
\hline $5360 \mathrm{R}$ & 5'-AGTGTGATTGAGGTGGAGTA-3' & $5380-5361$ \\
\hline $6080 \mathrm{~F}$ & 5'-TCTACAACGTTATCGTCACA-3' & $6061-6080$ \\
\hline $6340 R$ & 5'-CTAGGTGTAAGGAGAAGATG-3' & $6360-6341$ \\
\hline $6930 \mathrm{~F}$ & 5'-TGCAGTGCTCTGAGCCCTAG-3' & $6911-6930$ \\
\hline $7150 \mathrm{R}$ & 5'-GATTTACGCCGATGAATATG-3' & $7170-7151$ \\
\hline $7790 \mathrm{~F}$ & 5'-AACCGTCTGAACTATCCTGC-3' & $7771-7790$ \\
\hline 8050R & 5'-GAGTGCAAGACGTCTTGTGA-3' & $8070-8051$ \\
\hline $8740 \mathrm{~F}$ & 5'-ACGAACCTGATCTCTTATAC-3' & $8721-8740$ \\
\hline 8960R & 5'-GAATGAGTAGGCTGATGGTT-3' & $8980-8961$ \\
\hline $9660 \mathrm{~F}$ & 5'-CTGAGCTCACCATAGTCTAA-3' & $9641-9660$ \\
\hline 9940R & 5'-GAAATAGTCAAACCACATCT-3' & $9960-9941$ \\
\hline $10356 \mathrm{~F}$ & 5'-CTAAGTCTGGCCTATGAGTG-3' & $10,356-10,375$ \\
\hline 10760R & 5'-TTGGAGTAGGTTTAGGTTAT-3' & $10,760-10,741$ \\
\hline $11330 \mathrm{~F}$ & 5'-AGAACTATCAAACTCCTGAG-3' & $11,311-11,330$ \\
\hline 11610R & 5'-TTGAAGAGTATGCAATGAGC-3' & $11,630-11,611$ \\
\hline $12300 \mathrm{~F}$ & 5'-CAGCTATCCATTGGTCTTAG-3' & $12,281-12,300$ \\
\hline 12453R & 5'-TAATAAAGGTGGATGCGACA-3' & $12,472-12,453$ \\
\hline $13200 \mathrm{~F}$ & 5'-CTATCACCACTCTGTTCGCA-3' & $13,181-13,200$ \\
\hline 13430R & 5'-AGGTTGAAGTGAGAGGTATG-3' & $13,450-13,431$ \\
\hline $14070 \mathrm{~F}$ & 5'-ССАССТССАТСАТСАССТСА-3' & $14,051-14,070$ \\
\hline 14300R & 5'-TAATAGTGTAGGAAGCTGAA-3' & $14,320-14,301$ \\
\hline 14980F & 5'-ACGTAAATTATGGCTGAATC-3' & $14,961-14,980$ \\
\hline 15210R & 5'-GAACTAGGTCTGTCCCAATG-3' & $15,230-15,211$ \\
\hline $15990 \mathrm{~F}$ & 5'-TTAACTCCACCATTAGCACC-3' & $15,971-15,990$ \\
\hline 16306R & 5'-GTACTGTTAAGGGTGGGTAG-3' & $16,306-16,287$ \\
\hline \multicolumn{3}{|c|}{$\begin{array}{l}\text { Sense primers are designated as forward }(F) \text {, and antisense primers are desig- } \\
\text { nated as reverse }(R) \text {. Sequencing primers were designed to accommodate the } \\
700 \text {-bp sequencing limit with the BigDye Terminator version } 3.1 \text { Sequencing Kit. } \\
\text { In addition, the primers account for the } 80 \text {-bp of unreadable sequence directly } \\
\text { following the sequencing primers. }\end{array}$} \\
\hline
\end{tabular}

teinase $\mathrm{K}$ and $1 \%$ Tween ${ }^{\circledR} 20$ (SigmaAldrich, Milwaukee, WI, USA) in TE buffer $(10 \mathrm{mM}$ Tris- $\mathrm{Cl}, \mathrm{pH} 8.0,1 \mathrm{mM}$ EDTA)] were added to each tube, and a fourth cap with film still attached was placed in the opening of the tube to be simultaneously digested (http: //dir.nichd.nih.gov $/ \mathrm{lcm} / \mathrm{lcm} . h t m$; then follow DNA Analysis link). The tube was then inverted and flicked so that the proteinase $\mathrm{K}$ would coat and cover the cells on each film. Parafilm ${ }^{\circledR}$ was placed around the opening of the tube, and the inverted sample was placed at $37^{\circ} \mathrm{C}$ overnight. The digestion process was performed in exactly the same way for the opposing tissue condition.

\section{Double-Stranded PCR}

The next morning, after centrifuging the tubes briefly, the films were removed, and the proteinase $\mathrm{K}$ was inactivated at $95^{\circ} \mathrm{C}$ for $10 \mathrm{~min}$. Two microliters of the digested solution were added to each of the $18(100 \mu \mathrm{L})$ reactions, which consist of $2 \mu \mathrm{L} 10$ mM dNTPs (Roche Applied Science, Indianapolis, IN, USA), $6 \mu \mathrm{L} 25 \mathrm{mM}$ $\mathrm{MgCl}_{2}, 1 \mu \mathrm{L}$ AmpliTaq Gold ${ }^{\circledR}, 10 \mu \mathrm{L}$ GeneAmp ${ }^{\circledR} 10 \times$ gold buffer (all from Applied Biosystems), $1.5 \mu \mathrm{L} 10$ pmol/ $\mu \mathrm{L}$ forward primer, $1.5 \mu \mathrm{L} 10 \mathrm{pmol} / \mu \mathrm{L}$ reverse primer (Integrated DNA Technologies, Coralville, IL, USA), and $76 \mu \mathrm{L}$ double-distilled water. PCR was initiated at $95^{\circ} \mathrm{C}$ for $7 \mathrm{~min}$. The samples were then cycled as follows: 35 cycles of $94^{\circ} \mathrm{C}$ for $1 \mathrm{~min}, 55^{\circ} \mathrm{C}$ for $1 \mathrm{~min}$, and $72^{\circ} \mathrm{C}$ for $1 \mathrm{~min}$, with a 2 -s extension in a Genius Thermal Cycler (Techne, Cambridge, UK). The reactions were purified and concentrated according to the manufacturer's protocol using Microcon ${ }^{\circledR}$ PCR Filters (Millipore Bedford, MA, USA) that use centrifugation and water to quickly get rid of salts, dNTPs, and primers. Five microliters of each purified PCR product were electrophoresed on a $1 \%$ agarose gel containing $0.1 \mu \mathrm{g} / \mathrm{mL}$ ethidium bromide. Bands were viewed using an Eagle Eye II $^{\mathrm{TM}}$ Imaging System (Stratagene, La Jolla, CA, USA).

\section{Single-Stranded PCR and Sequencing}

For each double-stranded sample, a dilution was performed in distilled 


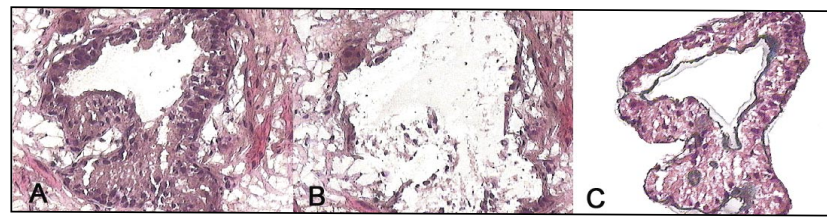

Figure 1. Normal tissue as viewed under a laser-capture microdissection microscope. (A) Benign acinus. (B) Tissue section after laser capture microdissection (LCM). (C) Benign acinus captured in a CapSure Macro Cap by LCM.



Figure 2. Tumor tissue as viewed under a laser capture microdissection microscope. (A) Malignant glands. (B) Tissue section after laser capture microdissection (LCM). (C) Malignant glands captured in a CapSure Macro Cap by LCM. water according to band strength: strong (1:30), medium (1:20), or weak (1:10). A portion $(12.8 \mu \mathrm{L})$ of the diluted sample was added to the singlestranded reaction that consisted of 3.2 $\mu \mathrm{L} 1 \mathrm{pmol} / \mu \mathrm{L}$ primer (Table 1 ) and 4 $\mu \mathrm{L}$ BigDye ${ }^{\mathrm{TM}}$ Terminator from the Big-

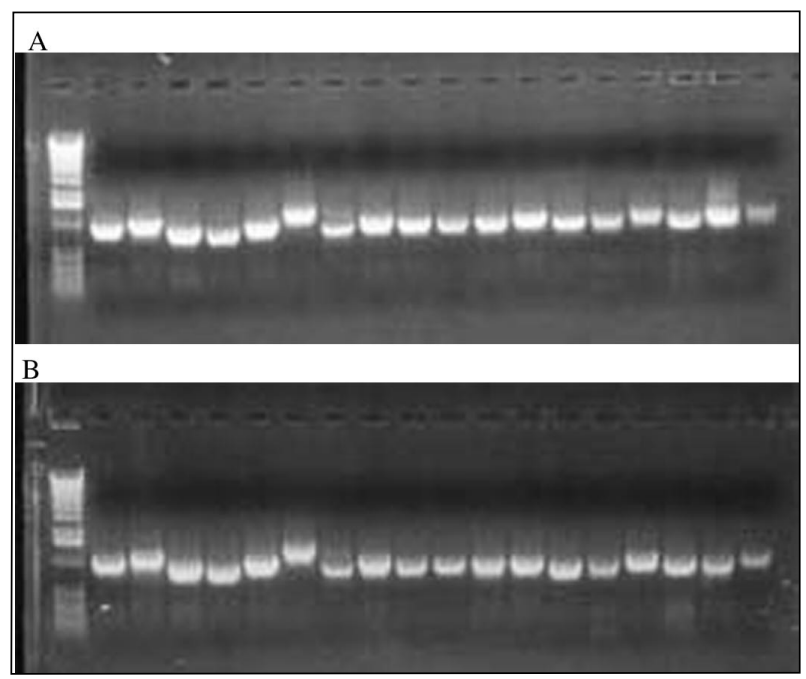

Figure 3. Double-stranded regions 1-18 from patient 264 tumor and normal tissues. Both (A) tumor and (B) normal tissues from patient number 264 were amplified and electrophoresed. The bright bands indicate substantial amplification. The PCR controls were run without template and appeared negative.
Dye Terminator v. 3.1 Sequencing Kit (Applied Biosystems). The 36 sequencing reactions were cycled as follows: $96^{\circ} \mathrm{C}$ for $1 \mathrm{~min}$ and 25 cycles of $96^{\circ} \mathrm{C}$ for $10 \mathrm{~s}, 55^{\circ} \mathrm{C}$ for $5 \mathrm{~s}$, and $60^{\circ} \mathrm{C}$ for 4 min in a Genius thermal cycler. Sequencing products were purified using Centrisep $^{\mathrm{TM}}$ Columns $(750 \times g)$ or Plates $(1500 \times g)$ (Princeton Separations, Adelphia, NJ, USA), following the manufacturer's protocol. This clean-up method uses gel filtration and centrifugation to eliminate salts, primers, and especially dye terminators that might be left after PCR. The purified samples were vacuum-dried from 45 min to $1 \mathrm{~h}$ on low heat, resuspended in $20 \mu \mathrm{L}$ $\mathrm{Hi}^{-D i^{\mathrm{TM}}}$ Formamide (highly deionized; Applied Biosystems), and sequenced with an ABI PrISM 3100 Genetic Analyzer.

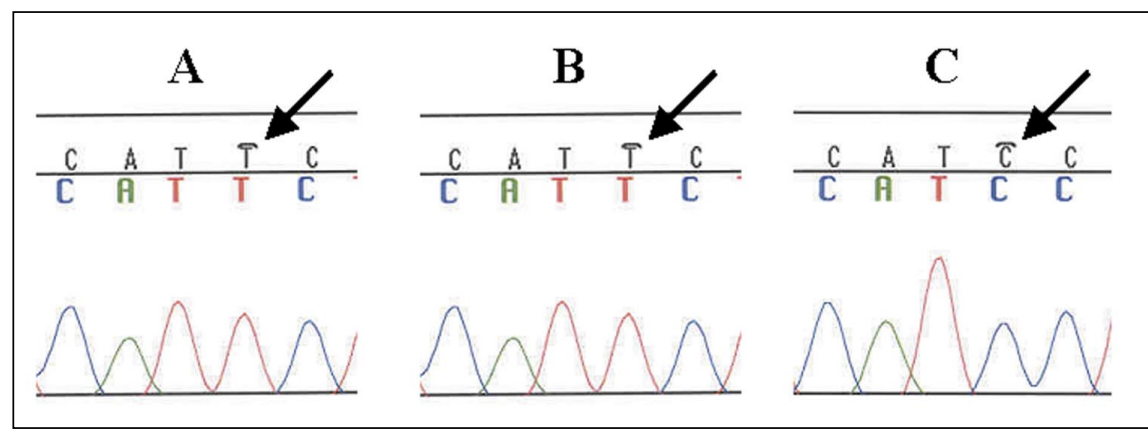

Figure 4. Single-stranded sequences showing polymorphism at $1 \mathrm{bp}$. Both (A) tumor and (B) normal tissues from patient number 264 show the nucleotide $T$ at base pair number 150 , compared to (C) the Cambridge mitochondrial sequence. This mutation (C150T) is a common polymorphism in the mitochondrial genome (http://www.mitomap.org).

\section{RESULTS AND DISCUSSION}

We have designed an accurate and efficient system for the amplification and automated sequencing of human mitochondrial genomes from LCM surgical samples. The nonneoplastic glands were from intermediate to large size, with irregular branching lumens and two cell layers. In contrast, the cancer glands were smaller in size, demonstrate irregular infiltration of the surrounding stroma, and have a single epithelial layer (Figures 1 and $2)$. Our system consists of primary PCR products that are large enough to allow for long sequencing runs but small enough to permit the amplification of relatively poor-quality template from clinical LCM samples. In addition, these primary reactions all anneal at the same temperature and salt concentration, which is a major advantage that increases the efficiency of this step. Strong bands from whole genome amplification were seen for each of the 18 double-stranded regions (Figure 3). The experiments were repeated seven times with the same result. The high-throughput automated sequencing capability of the ABI PRISM 3100 Genetic Analyzer further expedites the process without compromising sensitivity.

Our results were viewed using the Sequencher ${ }^{\mathrm{TM}}$ Gene Analysis Software version 4.0 (Gene Codes, Ann Arbor, MI, USA) as base sequences and chromatograms while being compared to the Cambridge-revised sequence for the mitochondrial genome (Figure 4). We were able to detect polymorphisms and mutations consistently and with high signal intensity. Heteroplasmy was also detectable, appearing on the chromatogram as two overlapping peaks at the same nucleotide position. 
In addition, we received reliable results in the highly variable D-loop region.

In summary, this system provides a quick and effective method for sequencing whole mitochondrial genomes from clinical LCM samples and has proven to be a valuable tool for comparing diseased and normal genomes.

\section{ACKNOWLEDGMENTS}

The authors would like to thank Douglas C. Wallace, Ph.D., for his support and collaboration.

\section{REFERENCES}

1.Cao, Z., J. Wanagat, S.H. McKiernan, and J.M. Aiken. 2001. Mitochondrial DNA deletion mutations are concomitant with ragged red regions of individual, aged muscle fibers: analysis by laser-capture microdissection. Nucleic Acids Res. 29:4502-4508.
2.DiMauro, S. and D.C. Wallace. 1993. Maternally inherited diseases, p. 63-83. In D.C. Wallace and M.T. Lott (Eds.), Mitochondrial DNA in Human Pathology. Raven Press, New York.

3.Jeronimo, C., S. Nomoto, O.L. Cabellero, H. Usadel, R. Henrique, G. Varzim, J. Oliveira, C. Lopes, et al. 2001. Mitochondrial mutations in early stage prostate cancer and bodily fluids. Oncogene 20:5195-5198.

4.Tanaka, M., M. Hayakawa, and T. Ozawa. 1996. Automated sequencing of mitochondrial DNA, p.407-421. In G.M. Attardi and A. Chomyn (Eds.), Methods in Enzymology, vol. 264. Academic Press, San Diego.

5.Tanaka, M. and T. Ozawa. 1994. Strand asymmetry in human mitochondrial DNA mutations. Genomics 22:327.

6.Bonner, R.F., M. Emmert-Buck, K. Cole, T. Pohida, R. Chuaqui, S. Goldstein, and L.A. Liotta. 1997. Laser capture microdissection: molecular analysis of tissue. Science 278: 1481-1483.

7.Emmert-Buck, M.R., R.F. Bonner, P.D. Smith, R.F. Chuaqui, Z. Zhuang, S.R. Goldstein, R.A. Weiss, and L.A. Liotta. 1996. Laser capture microdissection. Science 274:998-1001

8.Ren, Z., J. Sallstrom, C. Sundstrom, M. Nister, and Y. Olsson. 2000. Recovering
DNA and optimizing PCR conditions from microdissected formalin-fixed and paraffin-embedded materials. Pathobiology 68 : 215-217.

9.Polyak, K., Y. Li, H. Zhu, C. Lengauer, J.K.V. Wilson, S.D. Markowitz, M.A. Trush, K.W. Kinzler, et al. 1998. Somatic mutations of the mitochondrial genome in human colorectal tumours. Nat. Genet. 20: 291-293.

10.Wadehra, M., J. Braun, and L. Goodglick. 2002. One-step RT-PCR for screening microdissected tissue samples. BioTechniques 32 : 242-248.

Received 6 February 2003; accepted 5 June 2003.

Address correspondence to John A. Petros, Emory University School of Medicine, Department of Urology, 1365-B Clifton Road, Atlanta, GA 30322, USA. e-mail: jpetros@emory.edu 